\title{
Assessment of the Competitive Position of the V4 Group Countries in the Foreign Trade of Agri-food Industry Products
}

\author{
Anna S. KOWALSKA ${ }^{1}$, Klaudia GURKOWA ${ }^{1}$, Anna OLSZAŃSKA ${ }^{1}$, Ivan SOUKAL ${ }^{2 *}$ \\ and Martin MATEJICEK ${ }^{2}$ \\ 1 Wroclaw University of Economics and Business, Wroclaw, Poland; anna.kowalska@ue.wroc.pl; \\ klaudia.gurkowa@ue.wroc.pl; anna.olszańska@ue.wroc.pl \\ 2 University of Hradec Králové, Hradec Králove, Czech Republic; ivan.soukal@uhk.cz; \\ martin.matejicek@uhk.cz \\ * Corresponding author: ivan.soukal@uhk.cz
}

\begin{abstract}
The article is focused on the international competitive position of V4 countries in the foreign trade of agri-food industry products. The V4 countries' accession to the EU significantly changed exporters and importers' situation in these countries, providing them with better access to numerous markets. Integrating them into the single internal market area promoted trade and resulted in an increase of intra-EU exports and imports. The agri-food products market strongly benefited from such an opportunity, which was significantly limited before 2004 by duties and quotas. The article presents changes in international trade in agri-food products in the V4 countries and their competitiveness. We employ share of the analyzed country in global exports (EMS), import-export coverage (TC), revealed comparative advantages (RCA), and the intensity of intra-industry trade Grubel-Lloyd Index (GL) to assess the competitiveness. Our results show that Poland performed the best in international trade in agri-food products among the V4 countries. The result was confirmed by partial indicators and the total competitiveness index.
\end{abstract}

Keywords: trade; competitiveness; agri-food industry; export, import; V4 Group

JEL Classification: F10; F14; L66; Q17

\section{Introduction}

Over the years, the way of understanding the issue of competitiveness has significantly evolved. Thanks to the research conducted in this field, we know that the factors determining both the competitive potential and the competitive position of the country's economy have changed significantly with the overall global progress. From classical theories, where the basis for evaluation were factors of production, through neo-factor concepts and neotechnological hypotheses extended to include natural resources, in which knowledge was the reference point (Nosecka \& Pawlak, 2014). Over time, the factors changed, and with them, the very definition of the concept under discussion transformed. (Olczyk, 2008). Most often, the competitiveness of the economy, along with all its sectors and entities, is characterized not only in multi-level, but also multithreaded perspective. However, it is worth noting that 
despite its complexity, it has become one of the most important subjects of reflection for scientists in the fields of economics, politics, and even management.

As for the issues related to competitiveness analysis, they have been present in the literature for years; however, they do not lose their relevance. Observations at the international level prove that this aspect is important both from the point of view of the economy and economic policy, and even the country's business practice (Voinescu \& Moisoiu, 2015). This can be directly related to one of the most important documents concerning the competitiveness of countries in the world, i.e., the World Competitiveness Yearbook. The report published by the Swiss International Institute for Management Development (IMD) every year since 1989 proves that detailed research in this field can provide solutions to important problems. They concern such pillars as macroeconomic stability, financial system, business dynamism, labor market, product market, innovation, skills, and abilities (Schwab, 2019). Moreover, the complexity of the issue and the multiplicity of determinants and measures characterizing the state's competitiveness are so important on the international arena level that it is subject to constant discussions by such units as: the World Bank, the European Commission or the Organization for Economic Cooperation and Development (OECD). The noticeable relationship between economic growth and the global socio-ecological system's capacity affects decisions concerning not only the authorities but also the inhabitants of each country (Hämalainen, 2003). In the end, it is the society that reacts to top-down decisions with its behaviour.

It is important to note that the state's adjustment as a whole, along with its economy, entities, sectors, power, and society, to subsequent projects is aimed at ensuring the best position among other rivals. International competitiveness is most often defined as the state's general ability to effectively grow, and therefore to build wealth that is proportionately larger than its competitors on the world market (Mróz, 2016). Its particular attractiveness for the scientific sphere comes from the close connection with such aspects as, for example, the high standard of living and country's food policy. The relationship with the demand, supply, structure, and competition strategy strongly influences the ongoing research in this area (Trail \& Pitts, 1998). Thanks to this, it is certain that the literature and the theories it contains are constantly updated and expanded with new achievements.

Everything points to a multidirectional tendency in considering competitiveness. Thanks to the specification of three factors such as growth, integration, and sustainable development, it becomes easier to understand competitiveness through the prism of dynamic changes that surround us from everywhere. It has been suggested that attention should be paid to nonprice factors such as the impact of government intervention. Moreover, growing attention is paid to the agri-food sector's role and the fact that its impact on countries' competitiveness is increasing (Latruffe, 2010). This proves that the world population is growing. Therefore, new problems and challenges arise in the category of food policy, i.e., issues underlying the state's governing and management.

The current situation, although changeable and unstable, is also subject to evaluation and discernment. Issues related to the globalization of economic systems, advances in communication and transport technologies, reduction of logistics costs, and a very significant 
evolution of demand patterns require a detailed settlement (Carraresi \& Banterle, 2008). There are so-called ex-post and ex-ante group of factors. They are helpful when a researcher or a policy-maker intends to assess the position and the chances of progress in the long term (Misala, 2011). Therefore, for the purposes of this study, four indicators from this group were selected and used in the data compilation process.

The research area, not without reason, covers the countries of the Visegrad (V4) Group. The group called the V4 Four, or V-4 for short, is a regional form of cooperation between four countries of Central and Eastern Europe: Poland, Slovakia, Hungary, and the Czech Republic. These neighbouring countries are similar in terms of such features as, for example, tradition, culture, social values, geopolitical conditions, and, not infrequently, common history and therefore constitute an interesting research object (Kowalska \& Gurkowa, 2020). These countries underwent gradual liberalization of trade and economic integration at the global and regional levels (Molendowski, 2014). They opened their economies from the beginning of the transformation process in the 1990s. However, the process flow was not uniform. The most important issues were included in this study.

This article aims to assess the competitive position in the foreign trade of agri-food industry products among the V4 Group member states.

\section{Methodology}

In the article, selected indicators of ex-post competitiveness were used to assess the international competitiveness of the agri-food industry. Ex post competitive position indicators can be divided into three groups: comparative advantage measures, measures of market shares or international trade, and measures of price-cost competitiveness (Kraciński, 2018). In order to assess changes in the global trade in agri-food products of the V4 countries, basic methods of statistical analysis of data and selected quantitative measures were used, including mainly the results of foreign trade, i.e., the balance of trade in products of a given industry, Export Market Share (EMS) (1), Trade Coverage (TC) (2), Revealed Comparative Advantage (RCA) (3), Grubel-Lloyd's intra-industry trade indicators (GL) (4).

Following factors were used to measure the competitive position of agri-food products exported from the V4 countries to the global market:

1. Index of the share of the analysed country in world exports (EMS), which is expressed by the formula (Poland Statistical Office, 2018):

$$
E M S=E_{i j} / E_{i N}
$$

where:

E - exports in terms of value (USD/EUR),

$\mathrm{i}$ - analysed group of goods,

j - analysed country,

$\mathrm{N}$ - all countries.

This indicator is one of the simplest indicators measuring the competitive position. The increase in the share in exports of a given country in a specific group of goods is interpreted as an improvement in its competitive position (Zawiślińska, 2003). 
2. Import-export coverage ratio (TC), calculated according to the formula (Olszańska, 2016):

$$
\mathrm{TC} i=\mathrm{E} i / \text { I } \mathrm{x} 100
$$

where:

E - exports in terms of value (USD/EUR),

I - import in terms of value (USD/EUR),

i - analysed group of goods.

The TC index level above1 means that the country generates a surplus in trade in agrifood products and, as a result, has a competitive advantage in the exchange of products of this group. The value of the index below 1 means a deficit in trade turnover, which proves a weak competitive position in foreign markets (Kowalska, 2017).

3. Revealed Comparative Advantage Index (RCA), which measures, for example, the share of the agri-food industry in a country's total exports in relation to the share of this industry in total global exports. The indicator is expressed by the formula (Balassa, Noland, 1989):

$$
R C A i=E i j / E_{T j}: E i_{N}
$$

where:

E - export in terms of value (USD/EUR),

i - analysed group of goods,

j - analysed country,

$\mathrm{N}$ - all countries,

$\mathrm{T}$ - all goods.

The indicator takes values from 0 to infinity. If RCA $>1$, the agri-food industry of a given country has revealed comparative advantages, and therefore it is competitive. If, on the other hand, $0<$ RCA 1 , the analysed country has no revealed comparative advantages in global exports (Szczepaniak, 2017).

4. The Grubel-Lloyd Index (GL) measures the intensity of intra-industry trade. It is calculated according to the formula (Grubel \& Lloyd, 1975):

$$
G L=1-\left|E_{i j}-I_{i j}\right|:\left(E_{i j}+I i j\right)
$$

where:

E - export in terms of value (USD/EUR),

i - analysed group of goods,

j - analysed country.

The indicator takes values in the range (0.1). Level 0 means that all exchange has the nature of an inter-industry exchange (only exports or only imports of food products occur). Level 1 means that the entire exchange is of an intra-industry nature (the value of exports equals the value of imports) (Kowalska et al., 2017).

To determine the ranking of the V4 countries with the highest competitiveness in international trade in agri-food products, the partial indicators, i.e., EMS, TC, RCA, GL, were 
standardized (using a program), on the basis of which the so-called summary index of competitiveness (i.e., the arithmetic mean of the four partial indices).

The agri-food industry has been defined on the basis of the international nomenclature of the uniform classification of products, i.e., the Harmonized Commodity Description and Coding System, or HS for short. This nomenclature is used by over 200 countries worldwide, including the European Union, China, the United States, and Japan. The analysed data concerned the value of exports, imports, and the agri-food industry's trade balance in the V4 Group countries in 2001-2019. The source of all data was the International Trade Statistics TRADE MAP - ITC.

\section{Results and Discussion}

\subsection{Value of Trade in the V4 Countries with Products of the Agri-food Industry}

The data analysis showed that the exports of agri-food industry products in individual V4 countries in the years 2001-2019 varied (Fig. 1). Among the V4 countries, the highest value of exports, both in the last year and in the entire analysed period, was achieved by Poland while the lowest values were recorded in Slovakia. The value of exports of agri-food products in individual countries of the V4 Group in 2019 amounted to Poland (EUR 30.84 billion), Hungary (EUR 9.35 billion), the Czech Republic (EUR 7.71 billion), and Slovakia (EUR 2.91 billion). The value of exports of agri-food products of these countries increased in relation to the exports carried out in 2001, respectively: Poland - almost 8.4-fold, Slovakia - more than 4.6-fold, the Czech Republic - over 4.3-fold and Hungary - 3.2-fold. The average annual increase in the value of exports of agri-food industry products in the years 2001-2019 in individual V4 countries was, respectively: Poland on average by EUR 1.568 billion, Hungary by EUR 0.4097 billion, the Czech Republic on average by EUR 0.399 billion and Slovakia by on average EUR 0.156 billion. In the case of all V4 countries, the fit of the trend line was at a very good level - above 0.8 , which may indicate a further possible increase in the value of exports of agri-food industry products from these countries to international markets.

Import of agri-food products has also been growing in the countries discussed, although not as fast as exports. In 2019, agri-food industry products with a total value of over EUR 41.2 billion were imported to the V4 countries. The largest amounts of products were imported to Poland; these were commodities with a total value of almost EUR 20.6 billion, while the smallest quantity of goods, worth EUR 4.79 billion - were imported to Slovakia. In 2019, the value of imported agri-food products, compared to 2001, increased in all V4 countries. The most significant upturn showed Poland (more than 4.5-fold), then Hungary (almost 4-fold), and Slovakia (nearly 3.9-fold). The smallest one was found in the Czech Republic (approximately 3.7 times). The average annual increase in the value of imports of agri-food industry products in the years 2001-2019 in individual V4 countries was, respectively: in Poland by an average of EUR 0.979 billion, in the Czech Republic by an average of EUR 0.432 billion, in Hungary by an average of EUR 0.274 billion, and in Slovakia by an average of EUR 0.227 billion. 


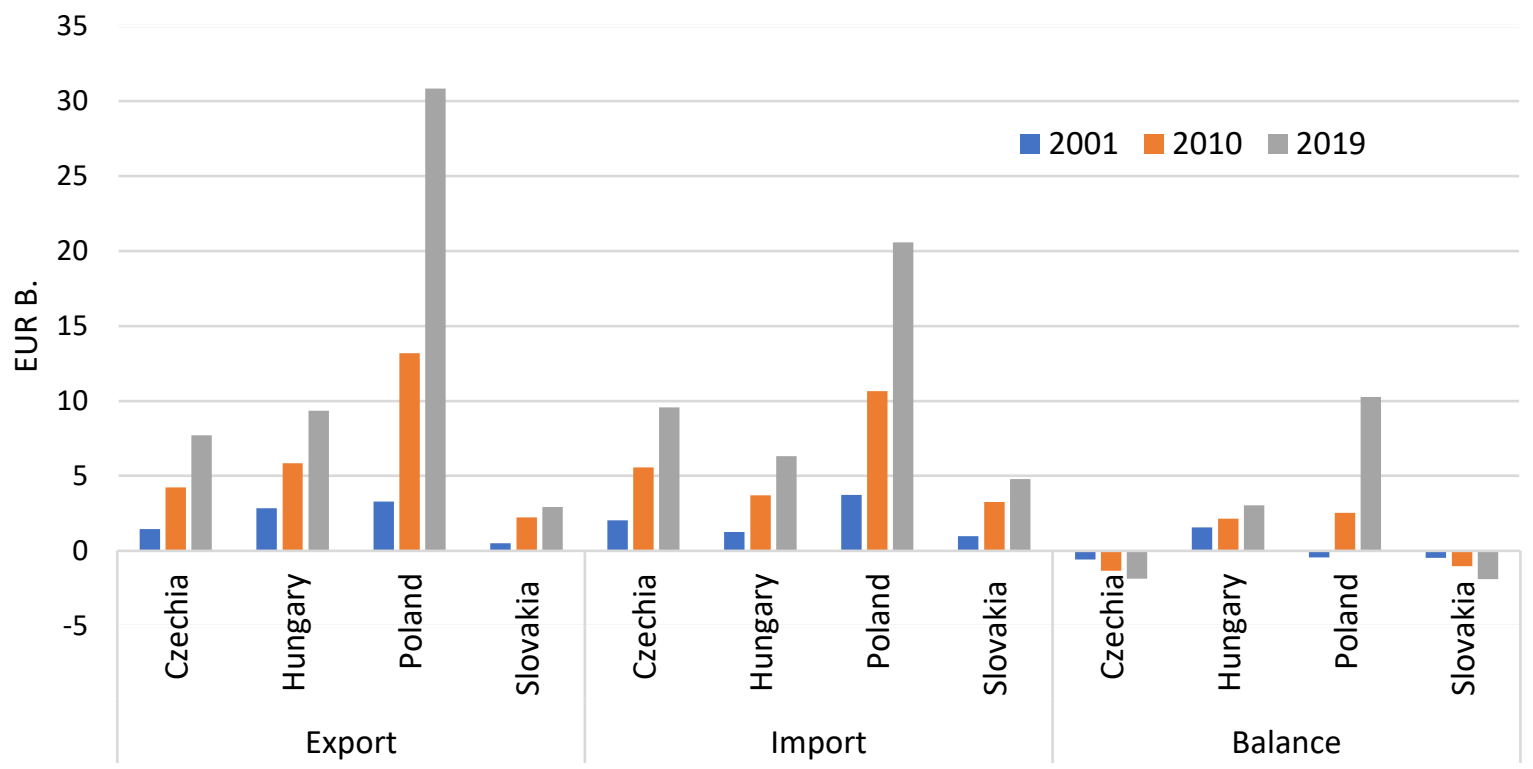

Figure 1. Exports, imports and the balance of trade in agri-food products in the V4 countries in 2001-2019. (International Trade Centre, 2020).

The exchange balance assessment showed that only Hungary in the discussed countries showed a positive balance of turnover. Poland started to achieve a positive trade balance after 2002, while the Czech Republic and Slovakia showed a negative turnover balance throughout the analysed period, proving that these countries were net importers of agri-food products throughout the analysed period.

\subsection{Assessment of the International Competitiveness of the Agri-food Industry of Individual V4} Countries

One of the most frequently used international competitiveness measures is the share in the export market (Doryń, 2019). In the years 2001-2019, Poland was of the greatest importance in the global export of agri-food products among the V4 group countries (Fig. 2). In 2019, the share of agri-food products exported from Poland to the world market amounted to $2.17 \%$ of the total agri-food exports, while the share of agri-food exports from other V4 Group countries in the global export of these products did not exceed $0.7 \%$. In the analysed period, the share of Polish agri-food exports in global exports increased in relation to its value in 2001 by 1.53 pp. The share of other countries of the V4 Group in the global structure of exports of agri-food products also increased in the analysed period, but it was lower than in Poland, and in relation to the value of 2001, it increased by 0.26 pp in the Czech Republic and by $0.1 \mathrm{pp}$ - in both Hungary and Slovakia. Annually, this share in the years 2001-2019 increased on average in the case of Poland by $0.078 \mathrm{pp}$, and the fit of the trend line was at the level of $\mathrm{R}^{2}=0.92$. The Czech Republic also showed a good fit $\left(\mathrm{R}^{2}=0.72\right)$, however, the average annual increase in the export share structure in the analysed period was only $0.014 \mathrm{pp}$ in the Czech Republic case. A linear trendline's $\mathrm{R}^{2} 0.7$ is high, which means that both countries' upward trend should continue in the coming years. 


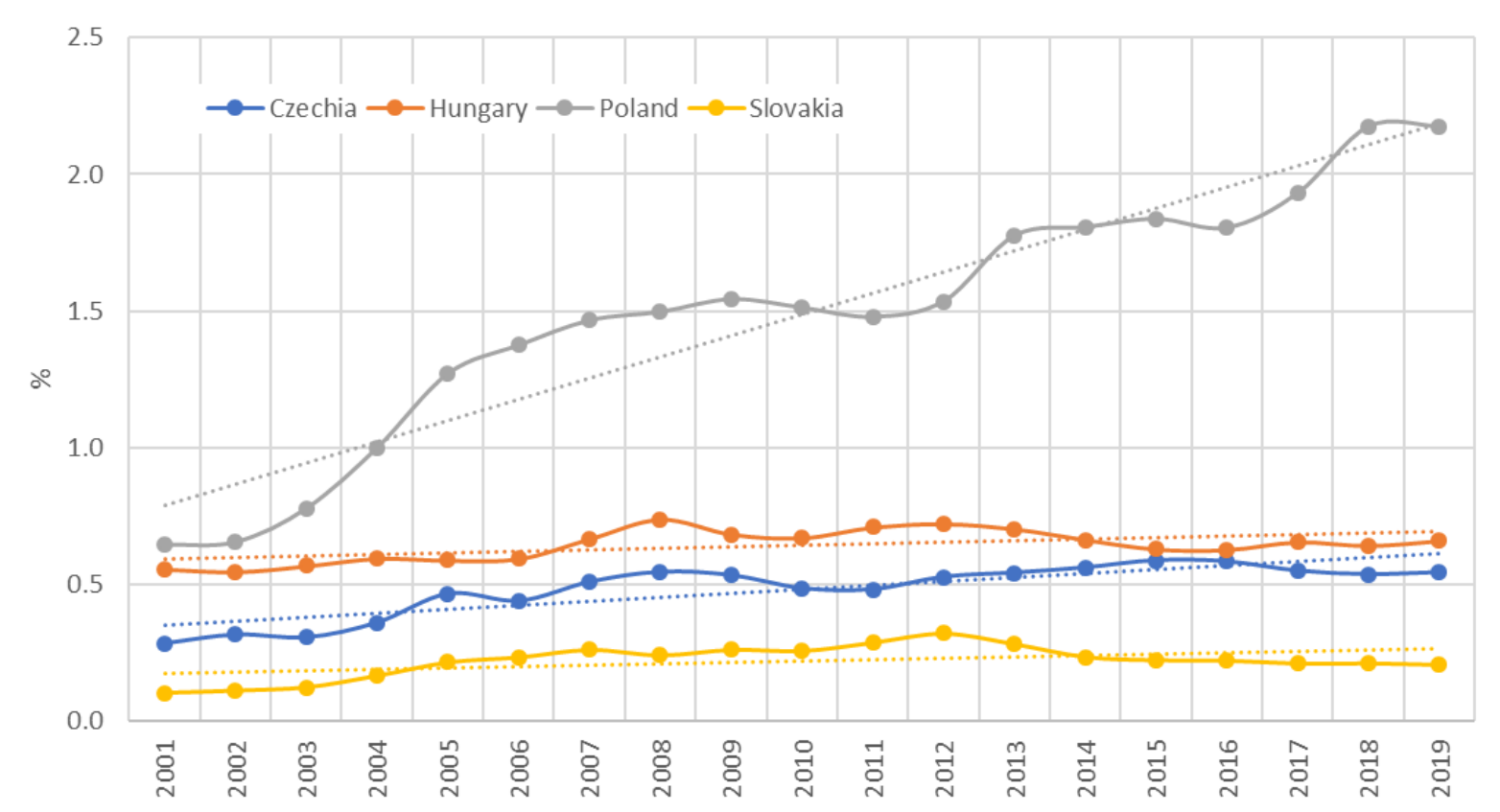

Figure 2. Indicators of the exports share of the V4 countries in the total exports of food industry products in 2001-2019. (International Trade Centre, 2020).

An important indicator to assess international competitiveness is the TC indicator, which shows the relationship between the value of exports and the value of imports (Rubaj, 2019). The values of this coefficient exceeding 1 mean the specialization of the studied country, which allows for the conclusion that it has a relative advantage over its partners (Lubiński et al., 1995; Pawlak et al., 2010). A trade deficit, i.e., a value below 1, indicates a weak position on international markets. A positive trade balance throughout the analysed period was shown by Hungary, while Poland reached the value of the indicator above 1 from 2003 (Fig. 3 ), and therefore it can be assumed that these countries are net exporters of agri-food products. The highest relative trade surplus among the surveyed countries was recorded in Hungary, especially in 2001, when the TC index was 2.24. In the following years, the value of TC index in Hungary's case showed a downward trend (a decrease of the index by 0.34 compared to 2001). The opposite situation was observed in the case of Poland, wherein the years 2001-2019, the TC index showed an upward trend, which means that the net surplus in this country was increasing year by year (the growth of the ratio by 0.7 compared to 2001). In 2019, both Poland and Hungary recorded a similar value of the TC indicator (at the level of 1.5). In three out of the four analysed countries, i.e., in the case of Poland, the Czech Republic, and Slovakia, the improvement in the international trade balance was related to an increase in exports. At the same time, there was also a systematic but much slower increase in the import of agri-food products in these countries. In the case of Hungary, the decrease in the coverage of imports with exports was due to a greater increase in the value of imports than the value of exports.

Countries from the V4 group, which were net importers of agri-food products throughout the examined period, i.e., showed a negative balance in foreign trade in the analysed products, are the Czech Republic and Slovakia. The net importer with an increase in import-export coverage was Slovakia. The value of TC index for Slovakia increased by 
15.6\% compared to 2001. In 2012, Slovakia showed the highest value of the TC index (0.9) in the analysed years. On the other hand, the Czech Republic is one of the net importers with a decrease in the coverage of imports with exports in the research period. In 2019, the Czech Republic recorded a 7\% decrease in the value of the TC index compared to 2001. In the case of the Czech Republic, the highest TC value of 0.82 was recorded in 2015.

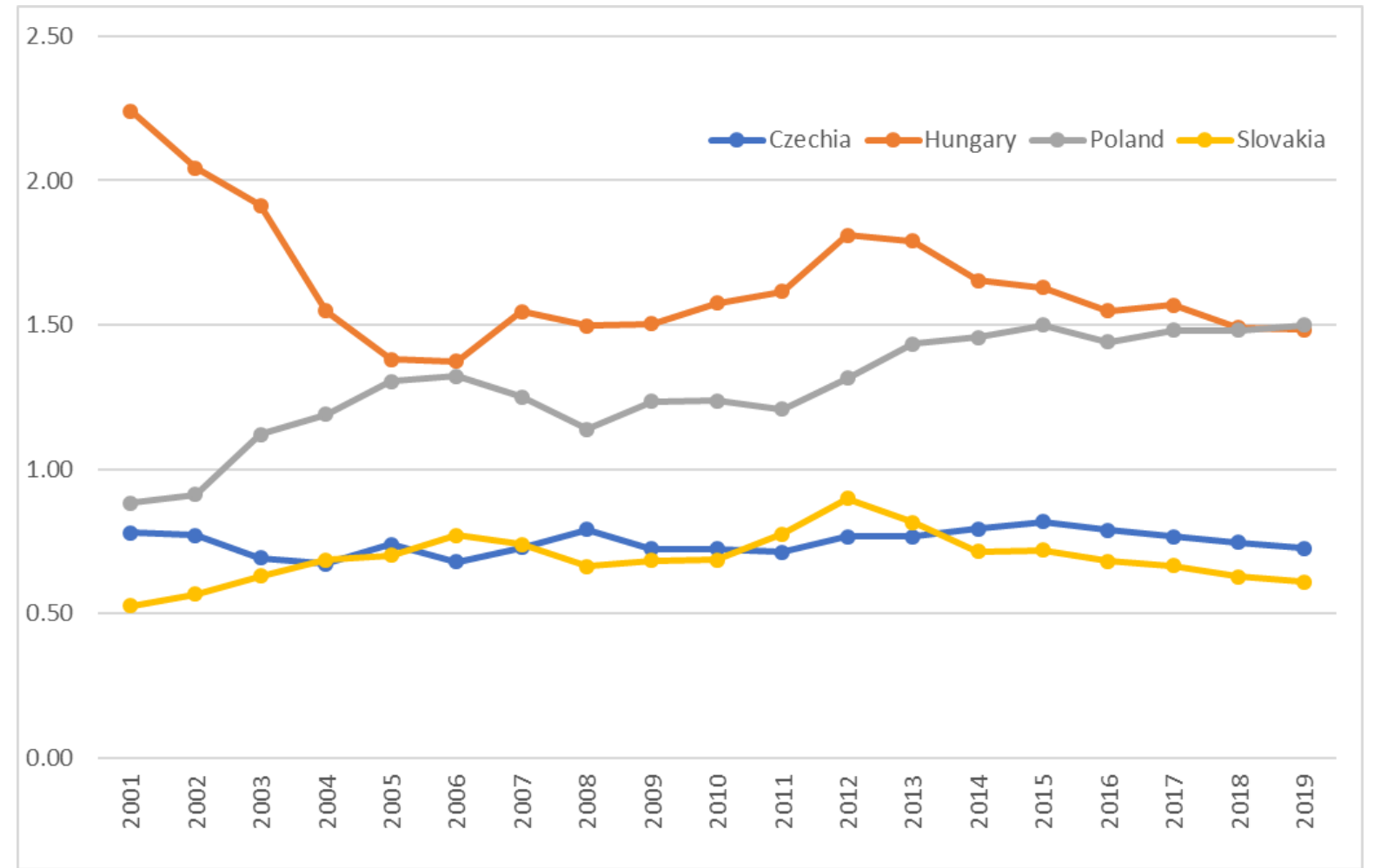

Figure 3. TC indicators in the global export of agri-food industry products of the V4 Group countries in 2001-2019. (International Trade Centre, 2020).

Another important indicator evaluating countries' competitiveness is the assessment of the revealed comparative advantages (Szczepaniak \& Wigier, 2020). It is assumed that the agri-food industry is competitive if the country has revealed comparative advantages. This means that the share of agri-food products in a given country's total exports is higher than the share of these products in global exports.

The RCA index level above1 and the revealed comparative advantages were achieved in the entire period under study in only one country belonging to the V4 Group - Poland. On the other hand, in Hungary, the value of this indicator fluctuated in the analysed period, and in most years of the research period, it exceeded the value of 1 (Fig. 4). In Poland, in the years 2001-2019, the RCA level ranged from 1.05 in 2002 to 1.64 in 2013. On the other hand, in Hungary, comparative advantages (ranging from 1.01 to 1.29) were achieved in the years 2001-2002; 2008-2015, 2017 and 2019. The RCA level below1 in the entire analysed period was recorded in the other 2 countries of the V4 Group. The Czech Republic and Slovakia did not achieve comparative advantages. It was only Poland which, among the countries of the V4 Group, strengthened its competitive position compared to 2001. The value of the indicator 
increased by almost $45 \%$. In other countries, the value of the indicator decreased compared to 2001.

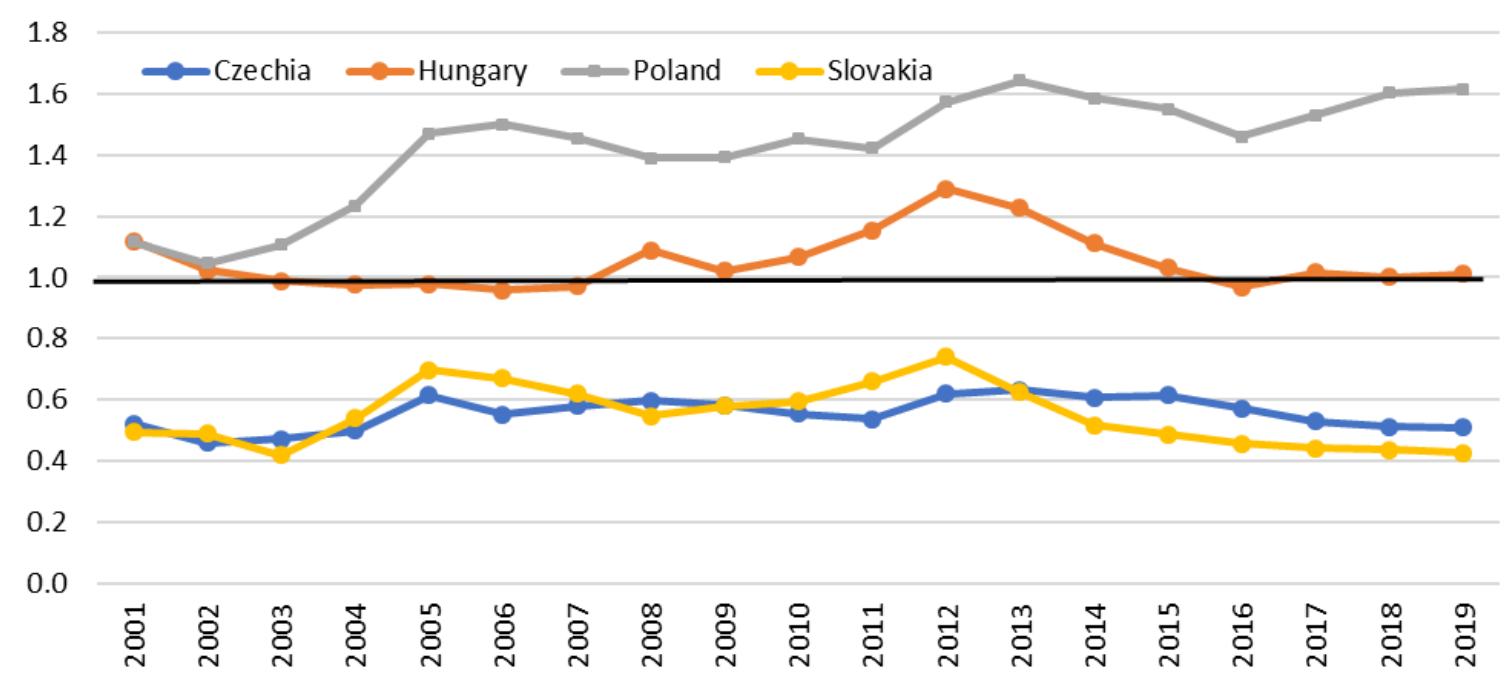

Figure 4. RCA indicators in the global export of agri-food products from the V4 Group countries to the world market in the period 2001-2019. (International Trade Centre, 2020).

The analysis of the intensity of intra-industry trade in products of the agri-food industry in individual V4 Group countries showed that in the analysed years, the volume of intraindustry exchange fluctuated. However, in all examined countries, at least $60 \%$ of the exchange was intra-industrial (Fig. 5).

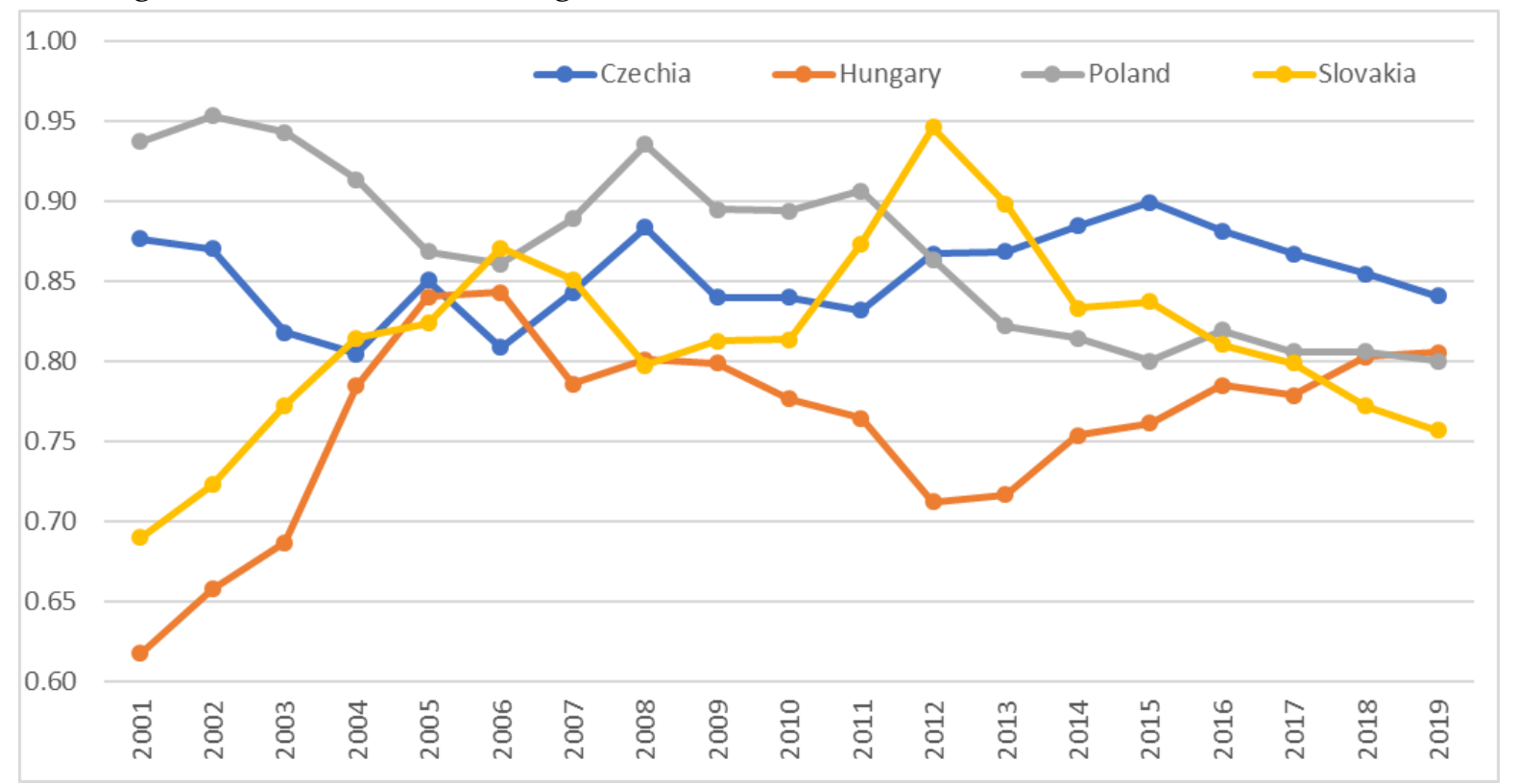

Figure 5. Grubel-Lloyd indicators in the world exports of agri-food products of the V4 Group countries in 2001-2019. (International Trade Centre, 2020).

In 2019, the Czech Republic had the highest level of intra-industry trade among the V4 countries (84\%). In 2001-2019, the intra-industry trade level in the Czech Republic was high, ranging from $80 \%$ in 2004 to $90 \%$ in 2015 . 
Among the V4 countries, Poland had the highest level of intra-industry trade in 20012011 (excluding 2006, when Slovakia overtook it). However, since 2008, there has been a systematic decrease in the intensity of intra-industry trade in Poland's case. A similar trend has also occurred in Slovakia since 2012. The share of intra-industry trade in Hungary in the analysed period was relatively low, although increasing again since 2012.

The calculated partial indices (EMS, TC, RCA, GL), obtained by individual countries of the V4 Group, were standardized. Then, on their basis, the total index of international trade competitiveness of the agri-food industry products of the countries in question in 2001-2019 was calculated, (Fig. 6).

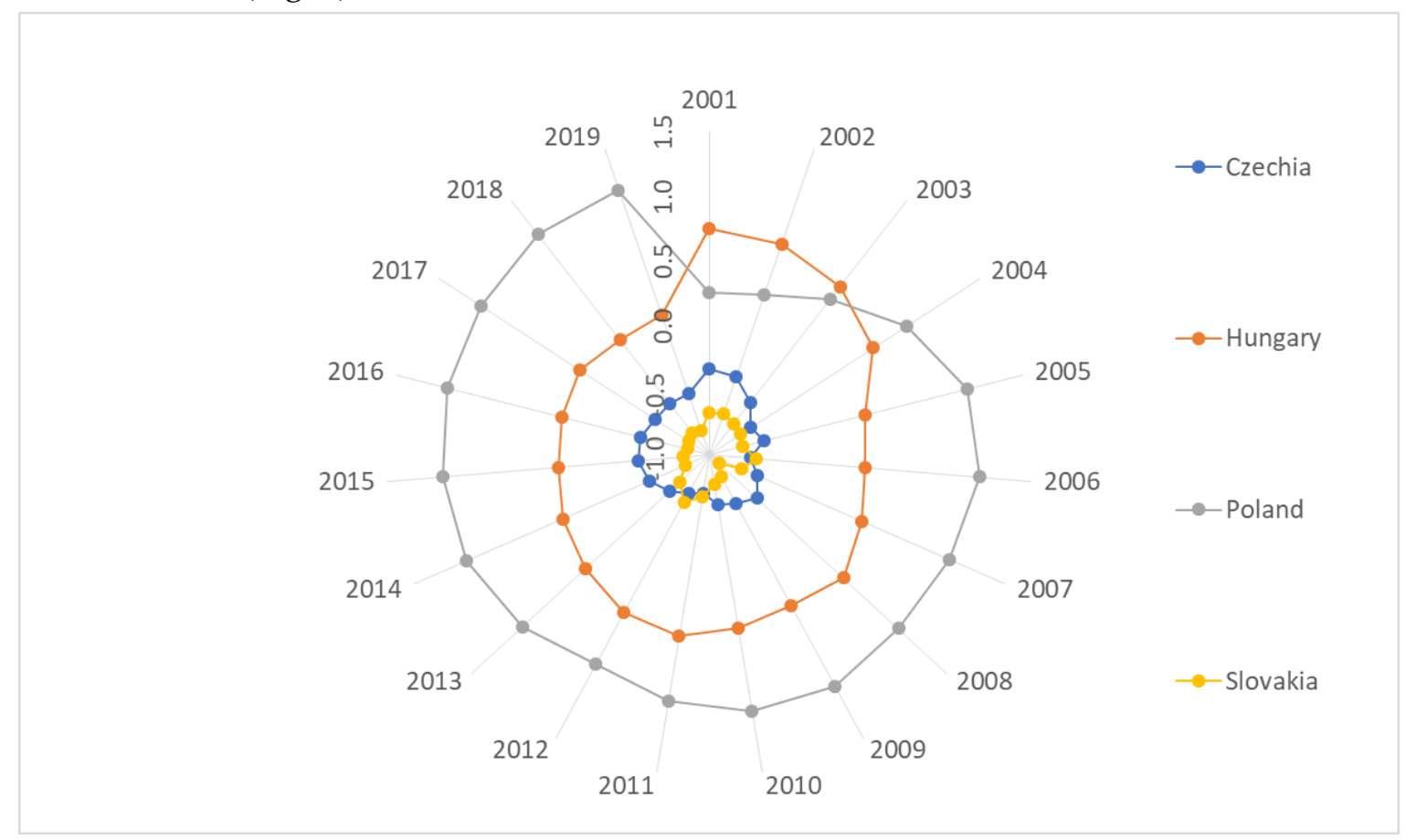

Figure 6. Ranking of the V4 Group countries' competitiveness in international trade in agri-food industry products based on a cumulative index. (International Trade Centre, 2020).

The obtained data showed that by 2003, Hungary achieved the best position in international trade among the V4 countries, while since 2004 (i.e., since the countries joined the European Union), Poland took the first position, and in subsequent years strengthened its advantage over other V4 countries. Slovakia was the last country in the ranking of the competitiveness of international trade in agri-food products in almost the entire analysed period (except for the years 2006, 2011 and 2012, when it was ranked 3rd, ahead of the Czech Republic).

\section{Conclusions}

The volume of foreign trade turnover of individual countries of the V4 group varied significantly, which is obviously largely related to their size and production potential of individual goods. However, general trends of changes are important in the analysis of data on the volume and value of foreign trade.

The entry of these countries into the uniform EU market and the significant opportunities for trade expansion were siezed in different degrees of success regarding agri-food products. 
The highest growth dynamics of agri-food exports was recorded in Poland. The Czech Republic and Slovakia had a nearly two-fold lower increase in exports. The lowest dynamics characterized Hungarian exports among the analysed countries.

Simultaneously, a consequence of the opening of markets within the Community was also an increase in imports. In the case of Poland, however, imports increased to a much lesser extent than exports. In the case of the Czech Republic and Slovakia, the scale of growth in imports and exports in 2019 compared to 2001 was similar. The increase in the value of imports of agri-food products to Hungary was more significant than in the case of exports. Despite this, only Hungary recorded a positive foreign trade balance in the analysed group of goods in the entire research period. The Czech Republic and Slovakia showed a negative foreign trade balance throughout the period. The dynamic growth in exports in Poland's case resulted in the permanently positive turnover balance recorded since 2003.

The reported values of RCA indicators also prove the favourable competitive position in international trade in agri-food products. In the entire analysed period, the values of these indicators for Poland were higher than 1 . In most years of the analysed period, in the case of Hungary, they were close to one. In 7 out of 19 examined years, they took more favourable values, but usually much lower than Poland's case. The RCA index values for the Czech Republic and Slovakia indicate a permanent lack of comparative advantages in trade in agrifood products.

Competitiveness indicators calculation summary allowed the assessment of the V4 countries' competitive positions and to follow the changes taking place over time. After the European Union's accession, Hungary's competitive position deteriorated, while Poland's position improved significantly. Compared to these countries, the Czech Republic and Slovakia's position was much worse and did not change significantly in the analysed years.

\section{References}

Balassa, B. E Noland, M. (1989). Revealed Comparative Advantage in Japan and the United States. Journal of International Economic Integration. 4(2), 8-22. https://doi.org/10.11130/jei.1989.4.2.8

Carraresi, L. \& Banterle, A. (2008). Measuring competitiveness in the EU market: a comparison between food industry and agriculture. (European Association of Agricultural Economists 2008 International Congress). European Association of Agricultural Economists. http://ageconsearch.umn.edu/record/43692/files/187.pdf

Doryń, W. (2019). Diversification of countries in terms of the share of domestic added value in exports. The Polish Statistician, 64(7), 32-47, https://doi.org/10.5604/01.3001.0013.7603

Grubel, H. G., \& Lloyd P. J. (1975). Intra-Industry Trade: The Theory and Measurement of Intra-Industry Trade in Differentiated Products. Macmillan.

Hämäläinen, T. J. (2003). National competitiveness and economic growth: the changing determinants of economic performance in the world economy. Elgar.

International Trade Centre. (2020). Trade Map [Data set]. Retrieved December 1, 2020, from https://www.trademap.org/Index.aspx

Kowalska, A., \& Gukowa, K. (2020). Development of Organic Farming in The V4 Group Countries After Accession to The European Union-Comparative Analysis. In S. Khalid (Ed.), Proceedings of the 35th IBIMA Conference (pp. 187-196). IBIMA Publishing Academic Publisher.

Kowalska, A. (2017). Polsko-niemiecka wymiana handlowa produktami rolno spożywczymi. Zeszyty Naukowe SGGW w Warszawie - Problemy Rolnictwa Światowego, 17(2), 106-115. https://doi.org/10.22630/PRS.2017.17.2.30

Kowalska, A., Tarnowska, A. \& Kovárník, J. (2017). Polish - Czech Trade in Agri-Food Products Before and after Accession to the European Union. In P. Jedlička, P. Marešová, I. Soukal (Eds.), Hradec Economic Days 2017 
(pp. 449-459). University of Hradec Králové.

https://uni.uhk.cz/hed/site/assets/files/1046/proceedings_2017_1.pdf

Kraciński, P. (2018). Konkurencyjność polskiego eksportu jabłek na rynki Wspólnoty Niepodległych Państw. Zeszyty Naukowe SGGW w Warszawie - Problemy Rolnictwa Światowego, 18(4), 13-22. https://doi.org/10.22630/PRS.2018.18.4.93

Latruffe, L. (2010). Competitiveness, Productivity and Efficiency in the Agricultural and Agri-Food Sectors (OECD Food, Agriculture and Fisheries Papers No. 30). https://doi.org/10.1787/5km91nkdt6d6-en

Lubiński M., Michalski T., \& Misala, J. (1995). The international competitiveness of the economy. The concept and method of measurement. Instytut Rozwoju i Studiów Strategicznych.

Misala, J. (2011). Międzynarodowa konkurencyjno's'c gospodarki narodowej. Polskie Wydawn. Ekonomiczne.

Molendowski, E. (2014). The V4 Group Countries - Changes in Intra-industry Competitiveness of their Economies During the World Financial and Economic Crisis. Procedia - Social and Behavioral Sciences, 110, 1006-1013. https://doi.org/10.1016/j.sbspro.2013.12.947

Mróz, J. (2016). Determinants and measures of the international competitiveness of the economy, In P. Urbanek, \& E. Walińska (Eds.) Economics and management science in the conditions of European integration (pp. 15-29). Wydawnictwo Uniwersytetu Łódzkiego.

Nosecka, B., \& Pawlak, K. (2014). Wybrane problemy konkurencyjności sektora rolno-spożywczego w Polsce i Unii Europejskiej. Instytut Ekonomiki Rolnictwa i Gospodarki Żywnościowej- Państwowy Instytut Badawczy.

Olczyk, M. (2008). Konkurencyjność: teoria i praktyka; na przykładzie polskiego eksportu artykułów przemysłowych na unijny rynek w latach 1995 - 2006. CeDeWu.

Olszańska, A. (2016). Handel zagraniczny Polski produktami mięsnymi w latach 1996-2014 - ocena tendencji na podstawie wybranych wskaźników. Zeszyty Naukowe SGGW w Warszawie - Problemy Rolnictwa Światowego, 232-241. https://doi.org/10.22004/AG.ECON.244348

Pawlak, K., Kołodziejczak, M., \& Kołodziejczak, W. (2010). Konkurencyjność sektora rolno-spożywczego nowych krajów członkowskich UE w handlu wewnątrzwspólnotowym. Zagadnienia Ekonomiki Rolnej, 1, 126-142.

Poland Statistical Office. (2018). Produkcja i handel zagraniczny produktami rolnymi w 2017 r. (Analizy statystyczne). Poland Statistical Office. https://stat.gov.pl/en/topics/agriculture-forestry/agricultural-andhorticultural-crops/production-and-foreign-trade-of-agricultural-products-in-2017,1,6.html

Rubaj, P. (2019). Teoretyczny i praktyczny wymiar międzynarodowej konkurencyjności gospodarki. Zeszyty Naukowe Uniwersytetu Ekonomicznego w Krakowie, 6(984), 7-24

Schwab, K. (2019). The Global Competitiveness Report 2019 (Insight Report). World Economic Forum. http://www3.weforum.org/docs/WEF_TheGlobalCompetitivenessReport2019.pdf

Szczepaniak, I., \& Wigier, M. (2020). Polski biznes rolno-spożywczy wczoraj i dzisiaj - czynniki sukcesu. In R. Przygodzka \& E. Gruszewska (Eds.), Instytucjonalne i strukturalne aspekty rozwoju rolnictwa i obszarów wiejskich. Księga poświęcona pamięci dr hab. Adama Sadowskiego Profesora Uniwersytetu w Białymstoku (pp. 233256). Wydawnictwo Uniwersytetu w Białymstoku. https://doi.org/10.15290/isarrow.2020.11

Szczepaniak, I., \& Wigier, M. (2020). Polish agri-food business yesterday and today - success factors. In R. Przygodzka, E. Gruszewska (Eds.), Institutional and structural aspects of agriculture and rural development. A book in memory of dr hab. Adam Sadowski, Professor of the University of Biatystok (pp. 233-256). Wydawnictwo Uniwersytetu w Białymstoku.

Szczepaniak, I. (2017). Comparative advantages in Polish trade in agri-food products. In I. Szczepaniak (Ed.), Competitiveness of Polish food producers and its determinants (pp. 45-80). Monographs of the Multiannual Program No. 67. Instytut Ekonomiki Rolnictwa i Gospodarki śśywno ywnośściowej ciowej - PIB.

Trail, B., \& Pitts, E. (1998). Competitiveness in the Food Industry. Springer Science \& Business Media.

Voinescu, R., \& Moisoiu, C. (2015). Competitiveness, Theoretical and Policy Approaches. Towards a More Competitive EU. Procedia Economics and Finance, 22, 512-521. https://doi.org/10.1016/S2212-5671(15)00248-8 